\title{
Opsoclonus and lingual myoclonus due to organophosphate poisoning: images in clinical medicine
}

\author{
Chandrasekharan Rajasekharan, ${ }^{1}$ Sanu Watson Renjith, ${ }^{2}$ Thampi Jayapal ${ }^{2}$ \\ ${ }^{1}$ Department of Internal Medicine, Medical College Hospital, Thiruvananthapuram, Kerala, India \\ ${ }^{2}$ Department of Internal Medicine, Government Medical College Hospital, Thiruvananthapuram, Kerala, India
}

Correspondence to Professor Chandrasekharan Rajasekharan, drcrajasekharan@yahoo.com

\section{DESCRIPTION}

A 12-year-old girl was referred to the emergency services with a history of consumption of pesticide chlorpyrifos (chlorpyrifos ( 0,0 diethyl 10 (3,5, tricholoro-2-pyridyl) phosphorothioate)), an organophosphorus compound, followed by multiple episodes of vomiting. On examination, she was conscious. Her pulse rate was $100 / \mathrm{min}$, blood pressure 120/ $80 \mathrm{~mm} \mathrm{Hg}$, temperature $37^{\circ} \mathrm{C}$, and respiratory rate $22 / \mathrm{min}$, regular. Her pupils were of normal size and light reflex bilaterally. On the second day, she became drowsy, tachypnoeic and had hypersalivation. Her eye movement was abnormal but pupillary reaction was normal. On the third day, her neurological examination revealed bilateral complete ptosis and continuous, rapid, involuntary, multivectorial (horizontal and vertical), random, chaotic saccades in all directions, conjugate fast eye movements without intersaccadic intervals consistent with opsoclonus (Video 1). The pupils were bilaterally constricted with sluggish light reflex. There were repetitive, rhythmic jerks of the tongue, suggestive of lingualmyoclonus (Video 2). There was poor neck holding, areflexia and absence of gag reflex. Plantar response was absent bilaterally. The patient underwent endotracheal intubation for airway protection as she developed respiratory arrest. Pseudocholinesterase was 1500 U/1 (Ref: 4650-10 440 U/1). She was diagnosed to have opsoclonus, lingualmyoclonus due to organophosphorus poisoning (Intermediate

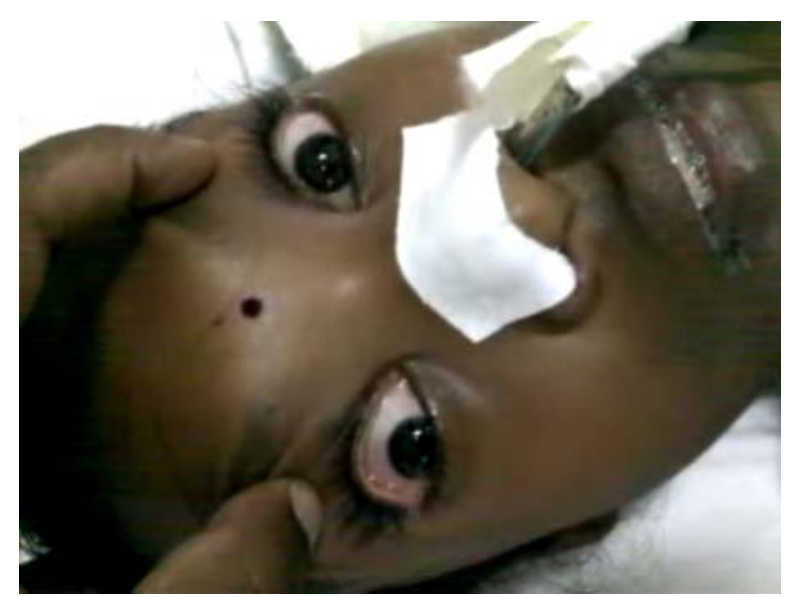

Video 1 Showing bilateral complete ptosis and continuous, rapid, involuntary, multivectorial (horizontal and vertical), random, chaotic saccades in all directions, conjugate fast eye movements without intersaccadic intervals consistent with opsoclonus.

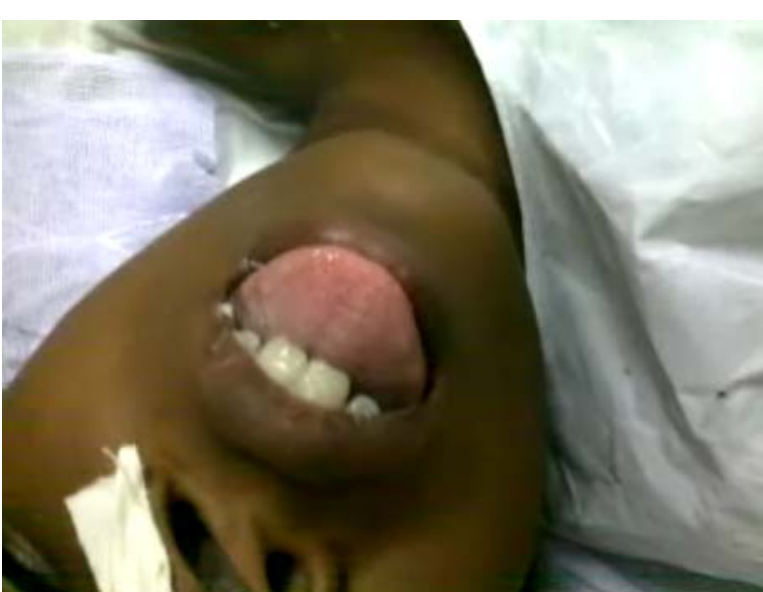

Video 2 There were repetitive, rhythmic jerks of the tongue suggestive of lingualmyoclonus.

Syndrome). She recovered with atropine, oximes and antibiotics. After 4 days on ventilator she was weaned off. Review at 3rd and 6th month was normal and she is currently under psychiatric follow-up.

\section{Learning points}

Eye movement disorders are one of the more common manifestations of organo-phosphate intoxication, and opsoclonus should now be included among these. ${ }^{1}$ The combination of opsoclonus, lingualmyclonus due to Intermediate Syndrome is uncommon.

- Opsoclonus is seen primarily in association with neuroblastomas, autoimmune processes or after viral encephalitis and paraneoplastic syndromes, and has also been described after ingestion of organophosphates, lithium, cetirizine, amitriptyline or diphenhydramine. ${ }^{2}$

\section{Competing interests None.}

Patient consent Obtained.

\section{REFERENCES}

1. Pullicino P, Aquilina J.Opsoclonusinorganophosphoruspoisioning. J Arch Neurol 1989;46:704-5.

2. Carstairs SD, Shneir AB. Images in clinical medicine. Opsoclonus due to diphenenhydramine poisoning. N Engl J Med 2010;363:e40. 


\section{BMJ Case Reports}

This pdf has been created automatically from the final edited text and images.

Copyright 2012 BMJ Publishing Group. All rights reserved. For permission to reuse any of this content visit http://group.bmj.com/group/rights-licensing/permissions.

BMJ Case Report Fellows may re-use this article for personal use and teaching without any further permission.

Please cite this article as follows (you will need to access the article online to obtain the date of publication).

Rajasekharan C, Renjith SW, Jayapal T. Opsoclonus and lingual myoclonus due to organophosphate poisoning: images in clinical medicine. BMJ Case Reports 2012;10.1136/bcr-2012-007043, Published XXX

Become a Fellow of BMJ Case Reports today and you can:

- Submit as many cases as you like

- Enjoy fast sympathetic peer review and rapid publication of accepted articles

- Access all the published articles

- Re-use any of the published material for personal use and teaching without further permission

For information on Institutional Fellowships contact consortiasales@bmjgroup.com

Visit casereports.bmj.com for more articles like this and to become a Fellow 